\title{
High-glucose-based peritoneal dialysis solution induces the upregulation of VEGF expression in human peritoneal mesothelial cells: The role of pleiotrophin
}

\author{
JIA LIU, XIA WU, YANCHUN LIU, YAGUANG XU, YUHAN HUANG, CHANGYING XING and XIAOYUN WANG \\ Department of Nephrology, First Affiliated Hospital, Nanjing Medical University, Nanjing, Jiangsu 210029, P.R. China
}

Received June 10,2013; Accepted August 27, 2013

DOI: $10.3892 / \mathrm{ijmm} .2013 .1491$

\begin{abstract}
The aim of the present study was to investigate the effect of a high-glucose-based peritoneal dialysis solution (HGPDS) on the expression of pleiotrophin (PTN) and vascular endothelial growth factor (VEGF) in human peritoneal mesothelial cells (HPMCs) and the mechanisms through which fluvastatin (Flu) protects the peritoneal membrane in continuous ambulatory peritoneal dialysis (CAPD). HPMCs were cultured with HGPDS, Flu $\left(10^{-8}-10^{-6} \mathrm{~mol} / \mathrm{l}\right)$ and PTN $(10-30 \mathrm{nmol} / \mathrm{l})$. The expression of PTN and VEGF was examined at the mRNA and protein level. To define the role of PTN in the regulation of VEGF expression, HPMCs were cultured with HGPDS in the presence or absence of the blocking peptide of PTN. The signaling pathways involved in PTN synthesis induced by HGPDS were also characterized. The phenotypic characteristics of HPMCs were observed under a light microscope. Cell viability was measured by 3-(4,5-dimethylthiazol-2-yl)2,5-diphenyltetrazolium bromide (MTT) colorimetry and the mRNA and protein expression of PTN, VEGF and ERK1/2 was assessed by RT-PCR and the western blot analysis, respectively. Following incubation with HGPDS for $48 \mathrm{~h}$, the morphology of the HPMCs changed from a typical cobblestone-like appearance to a fibroblast-like phenotype. The same alteration in the morphology of the HPMCs also occurred following incubation with $20 \mathrm{nmol} / 1$ PTN.Flu $\left(10^{-6} \mathrm{~mol} / \mathrm{l}\right)$, GSK650394 [a competitive inhibitor of serum/glucocorticoid-regulated kinase 1 (SGK1), $\left.10^{-5} \mathrm{~mol} / \mathrm{l}\right]$ and PD98059 (a competitive inhibitor of ERK1/2, $10^{-5} \mathrm{~mol} / \mathrm{l}$ ) improved the negative changes in cell morphology induced by HGPDS. The results of MTT assay revealed that the reduction in HPMC viability occurred in the groups treated
\end{abstract}

Correspondence to: Professor Xiaoyun Wang or Professor Changying Xing, Department of Nephrology, First Affiliated Hospital, Nanjing Medical University, 300 Guang Zhou Road, Nanjing, Jiangsu 210029, P.R. China

E-mail: chinakidney@sina.cn

E-mail: cyxing62@126.com

Keywords: fluvastatin, high-glucose peritoneal dialysate, human peritoneal mesothelial cells, pleiotrophin, vascular endothelial growth factor, serum and glucocorticoid-inducible kinase 1, extracelluar signal-regulated kinase with HGPDS and this reduction was partially restored by Flu, GSK650394 and PD98059. A significant improvement in cell viability, which had been decreased by HGPDS, was observed following treatment with Flu $\left(10^{-6} \mathrm{~mol} / \mathrm{l}\right)$, PD98059 $\left(10^{-5} \mathrm{~mol} / \mathrm{l}\right)$ or GSK650394 $\left(10^{-5} \mathrm{~mol} / \mathrm{l}\right)(\mathrm{P}<0.05)$. Compared with the control, the mRNA and protein expression of PTN and VEGF significantly increased in the HPMCs treated with HGPDS $(\mathrm{P}<0.05)$. GSK650394 and PD98059 significantly decreased the high mRNA and protein expression levels of PTN and VEGF induced by HGPDS $(\mathrm{P}<0.05)$ and Flu had the same inhibitory effect as GSK650394 and PD98059 in a dose-dependent manner $(\mathrm{P}<0.05)$. The mRNA and protein expression of VEGF increased following the incubation of HPMCs with $20 \mathrm{nmol} / 1$ PTN. By contrast, the mRNA and protein expression levels of VEGF in the HPMCs decreased in the presence of the blocking peptide of PTN. The results from the present study indicated that HGPDS increased the expression of PTN and VEGF in the HPMCs, and this increase was attenuated by Flu, GSK650394 and PD98059. The protein expression of phosphorylated ERK1/2 (p-ERK1/2) was decreased by GSK650394 in the HPMCs treated with HGPDS. Taken together, the protective effects of Flu in HPMCs may be partially achieved through the SGK1-ERK1/2 signaling pathway.

\section{Introduction}

Peritoneal dialysis (PD) has been used as the main therapy for the treatment of end-stage renal disease (ESRD). A single layer of mesothelial cells (MCs) covers an entire peritoneal cavity. This layer of MCs can serve not only as a biological barrier but also as a secretory organ. In addition, MCs have the ability to synthesize and secrete various substances, such as vascular endothelial growth factor (VEGF) and transforming growth factor (TGF) $\beta$ and these substances participate in the functional alteration of the peritoneal membrane (1-3). Sterile dialysis solutions universally applied are non-biocompatible, and can cause inflammation in the sub-mesothelium. The inflammation process may sequentially lead to fibrosis and angiogenesis, eventually leading to ultrafiltration failure (4). In patients on long-term PD using conventional peritoneal dialysis solutions (PDS), alterations in the structure and function of the peritoneal membrane, including increased peritoneal membrane permeability and ultrafiltration failure, eventually 
lead to peritoneal fibrosis $(6,7)$. The substances secreted by MCs play an important role in this process. Previous studies have suggested that VEGF plays an important role in the alteration of peritoneal membrane permeability $(8,9)$. Pleiotrophin (PTN), initially identified as a neurite growth/guidance-regulating protein, is an 18 - or $15-\mathrm{kDa}$ heparin-binding protein, which belongs to the midkine family $(10,11)$. PTN plays a variety of roles, including roles in proliferation and apoptosis and has mitogenic, angiogenic and oncogenic activities (12). In the studies by Kohashi et al (13) and Henger et al (14), PNT was reported to participate in fibrosis in different organs. A previous study demonstrated that the increase in peritoneal membrane permeability and fibrosis induced by chlorhexidine gluconate (CG) was attenuated in PTN knockout mice (15).

In this study, we investigated whether a high-glucosebased peritoneal dialysis solution (HGPDS) directly affects VEGF and PTN expression and whether this effect occurs through the modulation of the serum/glucocorticoid-regulated kinase 1 (SGK1)-ERK1/2 signaling pathway in human peritoneal mesothelial cells (HPMCs). We further explored the role of PTN in the modulation of VEGF expression in HPMCs.

\section{Materials and methods}

Materials. Fluvastatin (Flu) was obtained as a gift from Novartis Pharma Ltd., Shangai, China. Dulbecco's modified Eagle's medium (DMEM) and fetal bovine serum (FBS) were purchased from Gibco, Karlsruhe, Germany. Peritoneal dialysis fluids (4.25\%) (Baxter Corp., Deerfield, IL, USA) were used as co-culture medium. Rabbit polyclonal anti-PTN (Proteintech, Manchester, UK), rabbit polyclonal anti-VEGF (Abcam, Cambridge, MA, USA) and mouse anti-GAPDH monoclonal antibody (Wuhan Boster Biological Technology Ltd., Wuhan, China) were used for western blot analysis. GSK650394 (a competitive inhibitor of SGK1; Santa Cruz Biotechnology, Inc., Santa Cruz, USA) and PD98059 (an ERK specific inhibitor; Gibco) were used to observe the effects of SGK1 and ERK1/2 in HPMCs. Mouse anti-phosphorylated ERK1/2 (p-ERK) monoclonal antibody and mouse anti-ERK monoclonal antibody were purchased from Cell Signaling Technology, Inc., Danvers, MA, USA. A reverse transcription (RT) kit, TRIzol reagent and PremixTaq version 2.0 were purchased from Takara Bio, Inc., Shiga, Japan. 3-(4,5-Dimethylthiazol-2-yl)2,5-diphenyltetrazolium bromide (MTT) (Sigma, St. Louis, MO, USA) was used to assess cell viability.

Cell culture. HPMCs were obtained from the ATCC cell bank (no. CRL-9444) and were routinely grown in DMEM supplemented with fetal bovine serum (10\% FBS), $100 \mathrm{UI} / \mathrm{ml}$ penicillin and $100 \mu \mathrm{g} / \mathrm{ml}$ streptomycin. The cells were incubated at $37^{\circ} \mathrm{C}$ in a $5 \% \mathrm{CO}_{2}$ atmosphere and the culture medium was changed every 2-4 days. Cells were liberated with trypsin-EDTA to subculture in new dishes with a subcultivation ratio of $1: 3$ to $1: 4$. All experiments were conducted using cells at passage 5-10.

MTT. Cells were seeded into 96-well plates (4,000 cells/well) and cultured to $70-80 \%$ confluence. Following incubation in DMEM with $0.01 \%$ FBS for $48 \mathrm{~h}$, the cells were divided into different groups : i) control (a 1:1 mixture of DMEM and total culture fluid); ii) HGPDS (a 1:1 mixture of $4.25 \%$ PDS and total culture fluid); iii) HGPDS plus Flu $\left(10^{-8}-10^{-6} \mathrm{~mol} / \mathrm{l}\right)$, HGPDS plus GSK650394 $\left(10^{-5} \mathrm{~mol} / \mathrm{l}\right)$ or HGPDS plus PD98059 $\left(10^{-5} \mathrm{~mol} / \mathrm{l}\right)$; iv) Flu $\left(10^{-8}-10^{-6} \mathrm{~mol} / \mathrm{l}\right)$ (a $1: 1$ mixture of DMEM and total culture fluid), GSK650394 $\left(10^{-5} \mathrm{~mol} / \mathrm{l}\right)$ (a 1:1 mixture of DMEM and total culture fluid) or PD98059 $\left(10^{-5} \mathrm{~mol} / \mathrm{l}\right)$. Each treatment group had 6 replicate wells. Following incubation for $6,12,24,36,48$ or $72 \mathrm{~h}, 20 \mu \mathrm{l}$ of MTT $(5 \mathrm{mg} / \mathrm{ml})$ were added to each well and the plates were incubated for an additional $4 \mathrm{~h}$. Subsequently, the medium was discarded, $100 \mu \mathrm{l}$ of DMSO were added to each well and mixed thoroughly. The absorbance value of the wells was read at $490 \mathrm{~nm}$ using a microplate reader (Bio-Rad, Hercules, CA, USA).

RNA extraction and RT-PCR. Cultured HPMCs were randomly divided into the following groups: i) HPMCs were treated with HGPDS for 0, 6, 12 and $24 \mathrm{~h}$; ii) HPMCs were grown in medium with HGPDS and/or the addition of Flu $\left(10^{-8}-10^{-6} \mathrm{~mol} / \mathrm{l}\right)$, HGPDS plus GSK650394 (10 $\left.0^{-5} \mathrm{~mol} / \mathrm{l}\right)$, HGPDS plus PD98059 $\left(10^{-5} \mathrm{~mol} / \mathrm{l}\right), \mathrm{PTN}(10-30 \mathrm{nmol} / \mathrm{l})$ with or without the blocking peptide of PTN, Flu $\left(10^{-6} \mathrm{~mol} / \mathrm{l}\right)$, GSK650394 $\left(10^{-5} \mathrm{~mol} / \mathrm{l}\right)$ or PD98059 $\left(10^{-5} \mathrm{~mol} / \mathrm{l}\right)$ without HGPDS. First-strand cDNA synthesis was performed using $1 \mu \mathrm{g}$ of each RNA sample. A $2 \mu 1$ mixture was used in the PCR reaction with PremixTaq version 2.0 (loading dye mix). All specific primers for human PTN, VEGF, fibronectin (FN) and GAPDH were designed according to the sequences in GenBank: PTN: forward, 5'-CTTGGCATTCATTTTCAT-3' and reverse, 5'-GATCTT ACATCTCTGGGTCTT-3'; VEGF forward, 5'-ATGACGA GGGCCTGGAGTGT-3' and reverse, 5'-GGGATTTCTT GGGCTTTCGTTT-3'; FN forward, 5'-AGCCGCCACGTG CCAGGATTAC-3' and reverse, 5'-CTTATGGGGGTGGC CGTTGTGG-3' and GAPDH forward, 5'-AGGTCGGAG TCAACGGATTTG-3' and reverse, 5'-GTGATGGCAT GGACTGTGGT-3'. The annealing temperature was 51, 54, 59.4 and $60^{\circ} \mathrm{C}$, respectively. PCR was amplified using primers for human PTN, VEGF, FN and GAPDH and the products were subjected to electrophoresis on $2.5 \%$ agarose gels. The bands were visualized by ethidium bromide. Finally, analysis was performed by densitometric gel scanning. GAPDH was used as the housekeeping gene to normalize target gene expression. The results were expressed as the ratio of PTN, VEGF and FN to GAPDH in each sample analyzed.

Western blot analysis. Cells were divided into the same groups as for RT-PCR. Protein from the cells was homogenized in lysis buffer and was quantified. Each protein sample $(60 \mu \mathrm{g}$, apart from PTN $200 \mu \mathrm{g}$ ) was separated by $12 \%$ SDS-PAGE and transferred onto a nitrocellulose membrane for $60 \mathrm{~min}$ (apart from PTN $40 \mathrm{~min}$ ) at $100 \mathrm{~V}$ (apart from PTN $90 \mathrm{~V}$ ). Non-specific protein binding was blocked by incubating the membranes in blocking solution [5\% non-fat milk in TBS-0.1\% Tween-20 (TBS-T)] for $1 \mathrm{~h}$ at room temperature. The membrane was exposed overnight to a 1:500 dilution of rabbit polyclonal anti-human PTN, a 1:1,000 dilution of rabbit polyclonal anti-human VEGF antibody, a 1:2,000 dilution of mouse monoclonal anti-human ERK1/2 and p-ERK1/2 or a 1:500 dilution of mouse monoclonal anti-GAPDH antibody at $4^{\circ} \mathrm{C}$. After being rinsed with TBS-T solution 3 times, each membrane was incubated with horseradish peroxidase-conju- 

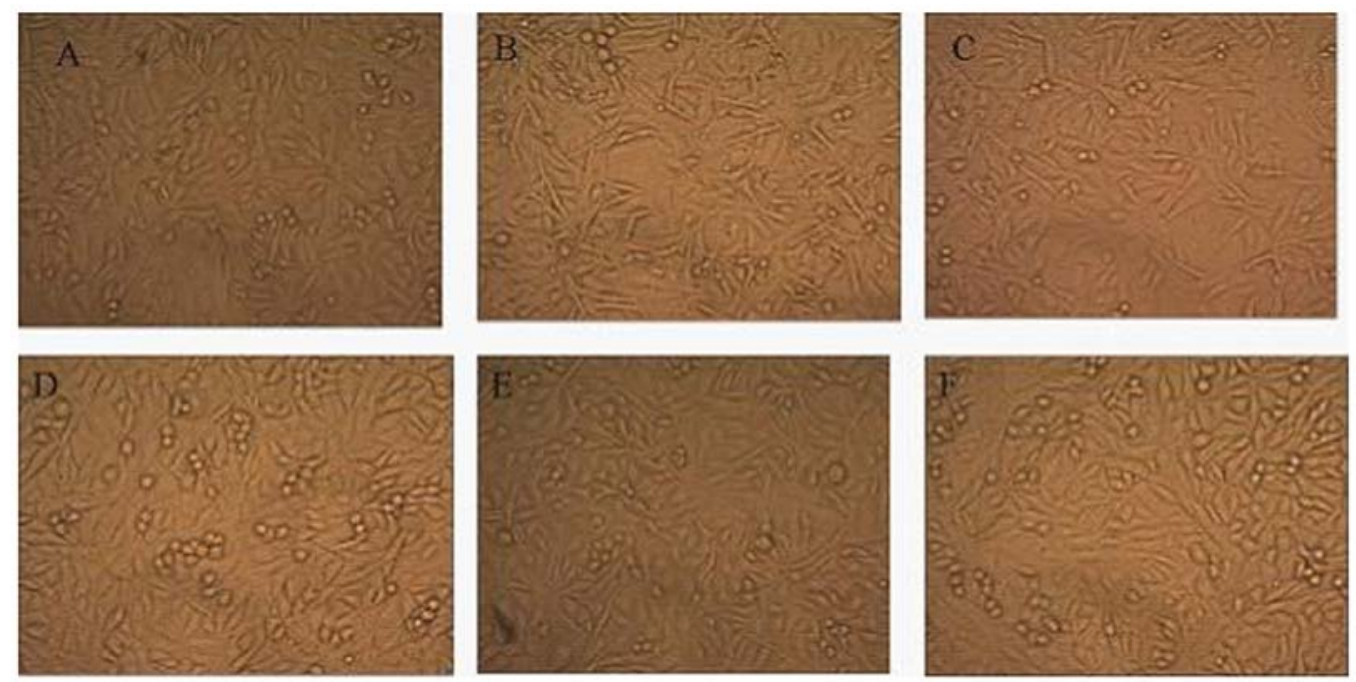

Figure 1. Morphological changes in cultured human peritoneal mesothelial cells (HPMCs). (A) control group; (B) high-glucose-based peritoneal dialysis solution (HGPDS) group; (C) $20 \mathrm{nmol} / 1$ pleiotrophin (PTN) group; (D) HGPDS + fluvastatin (Flu) 10-6 mol/1 group; (E) HGPDS + GSK650394 (a competitive inhibitor of SGK1) $10^{-5} \mathrm{~mol} / 1$ group; (F) HGPDS + PD98059 (a competitive inhibitor of ERK1/2) $10^{-5} \mathrm{~mol} / 1$ group. Normal HPMCs showed a cobblestone-like appearance (A), while the cells treated with HGPDS and PTN displayed a fibroblast-like morphology (B and C). The addition of either Flu $10^{-6} \mathrm{~mol} / 1, \mathrm{PD} 98059$ or GSK650394 $10^{-5} \mathrm{~mol} / \mathrm{l}$ to HGPDS attenuated the changes in cell morphology induced by HGPDS (D, E and F).

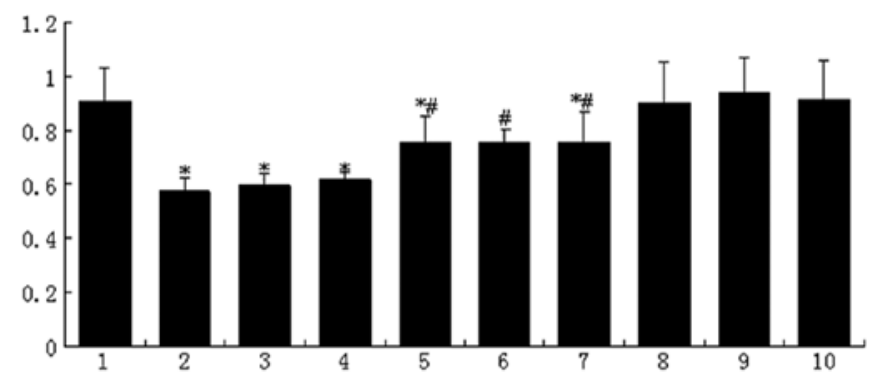

Figure 2. Cell viability decreased by high-glucose-based peritoneal dialysis solution (HGPDS). Lane 1, control; lane 2, HGPDS ; lane 3, HGPDS + fluvastatin (Flu) $10^{-8} \mathrm{~mol} / \mathrm{l}$; lane 4, HGPDS + Flu $10^{-7} \mathrm{~mol} / \mathrm{l}$; lane 5 , HGPDS + Flu $10^{-6} \mathrm{~mol} / 1$; lane 6, HGPDS + GSK650394 (a competitive inhibitor of SGK1) $10^{-5} \mathrm{~mol} / 1$; lane 7, GPDS + PD98059 (a competitive inhibitor of ERK1/2) $10^{-5} \mathrm{~mol} / \mathrm{l}$; lane 8, Flu $10^{-6} \mathrm{~mol} / \mathrm{l}$; lane 9, GSK650394 $10^{-5} \mathrm{~mol} / \mathrm{l}$; lane 10 , PD98059 $10^{-5} \mathrm{~mol} / \mathrm{l}$. Cell viability was decreased by HGPDS, while it was partially restored in the groups treated with 3 different concentrations of Flu or GSK650394. The decrease in cell viability induced by HGPDS was significantly reversed by the concentration of Flu $10^{-6} \mathrm{~mol} / 1$, PD98059 and GSK650394 $10^{-5} \mathrm{~mol} / 1 .{ }^{*} \mathrm{P}<0.05$ vs. control, ${ }^{,} \mathrm{P}<0.05$ vs. HGPDS.

gated secondary antibody [sheep anti-rabbit $\operatorname{IgG}(1: 10,000)$ or sheep anti-mouse IgG (1:10,000)] for $60 \mathrm{~min}$ at room temperature. After another wash with TBS-T solution, specific signals were detected using an enhanced chemiluminescence western blotting detection system. The bands were scanned using a laser densitometer to assess the density.

ELISA. Cells were disseminated into 12 -well plates $\left(10^{5}\right.$ cells/ well) and divided into the control group (a 1:1 mixture of DMEM and total culture fluid), HGPDS group (a 1:1 mixture of $4.25 \%$ PDS and total culture fluid) and $20 \mathrm{nmol} / \mathrm{l} \mathrm{PTN}$ group (a 1:1 mixture of DMEM and total culture fluid with the addition of $20 \mathrm{nmol} / \mathrm{l} \mathrm{PTN}$ ). After the cells were cultured under different conditions, the supernatants were collected and the FN protein from the supernatants was determined using a human fibronectin ELISA kit (R\&D Systems, Minneapolis,
MN, USA) according to the manufacturer's instructions. To control cell number differences in the supernatants, all proteins in each group were extracted and quantified by the BCA method. The FN levels were then expressed as ng/mg protein.

Statistical analysis. We used SPSS 13.0 software to analyze the results and all data are expressed as the means \pm SD. Comparisons among groups were performed by one-way ANOVA. A value of $\mathrm{P}<0.05$ was considered to indicate a statistically significant difference.

\section{Results}

Changes in phenotypic characteristics of HPMCs. The normal HPMC monolayer showed a characteristic cobblestone-like appearance; however, the loss of cell contacts with an acquisition of an elongated fibroblastic morphology was observed after $48 \mathrm{~h}$ of incubation with HGPDS. A similar morphology alteration was observed following incubation with PTN. Flu $\left(10^{-6} \mathrm{~mol} / \mathrm{l}\right)$, GSK650394 $\left(10^{-5} \mathrm{~mol} / \mathrm{l}\right)$ and PD98059 $\left(10^{-5} \mathrm{~mol} / \mathrm{l}\right)$ reversed the changes in cell morphology induced by HGPDS. GSK650394 $\left(10^{-5} \mathrm{~mol} / \mathrm{l}\right)$, PD98059 $\left(10^{-5} \mathrm{~mol} / \mathrm{l}\right)$ or Flu $\left(10^{-6} \mathrm{~mol} / \mathrm{l}\right)$ alone had no effect on the phenotypic characteristics of the HPMCs (Fig. 1).

Effect of HGPDS and Flu on cell viability. Cell viability was affected by HGPDS, GSK650394 $\left(10^{-5} \mathrm{~mol} / \mathrm{l}\right)$, PD98059 $\left(10^{-5} \mathrm{~mol} / \mathrm{l}\right)$ and Flu $\left(10^{-6} \mathrm{~mol} / \mathrm{l}\right)$. Compared with the control group, a reduction in HPMC viability was observed in the HGPDS groups and this reduction was partially reversed in the groups treated with various concentrations of Flu, PD98059 and GSK650394. After $24 \mathrm{~h}$ of incubation, the decrease in cell viability induced by HGPDS was reversed with the concentration of Flu $\left(10^{-6} \mathrm{~mol} / \mathrm{l}\right)$, GSK650394 $\left(10^{-5} \mathrm{~mol} / \mathrm{l}\right)$ and PD98059 $\left(10^{-5} \mathrm{~mol} / \mathrm{l}\right)(\mathrm{P}<0.05)$ (Fig. 2). 

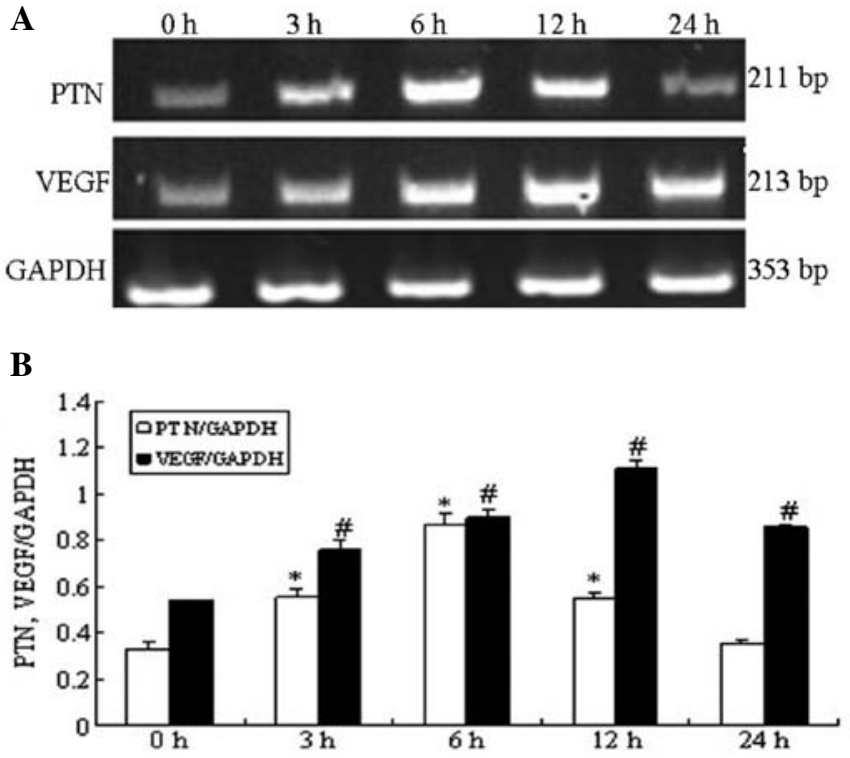

Figure 3. Effect of high-glucose-based peritoneal dialysis solution (HGPDS) on pleiotrophin (PTN) and vascular endothelial growth factor (VEGF) mRNA expression. (A) Analysis of PTN and VEGF mRNA expression by RT-PCR. (B) Densitometry analysis of PTN and VEGF mRNA. GAPDH was used as the housekeeping gene to normalize target gene expression. The mRNA expression of PTN and VEGF increased significantly following exposure to HGPDS, peaking at 6 and $12 \mathrm{~h}$ respectively. ${ }^{*} \mathrm{P}<0.05$ vs. $0 \mathrm{~h},{ }^{\sharp} \mathrm{P}<0.05$ vs. $0 \mathrm{~h}$.
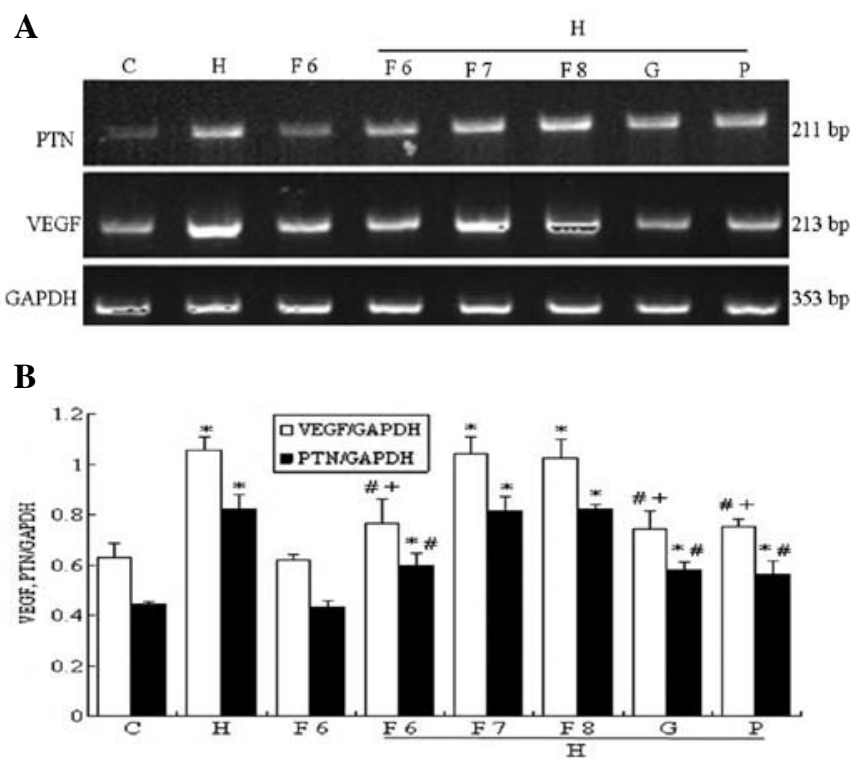

Figure 4. Effect of fluvastatin (Flu), GSK650394 (a competitive inhibitor of SGK1) and PD98059 (a competitive inhibitor of ERK1/2) on the highglucose-based peritoneal dialysis solution (HGPDS)-stimulated mRNA expression of pleiotrophin (PTN) and vascular endothelial growth factor (VEGF). C, control; H, HGPDS; F6, Flu $10^{-6} \mathrm{~mol} / \mathrm{l}$; H + F6, HGPDS + Flu $10^{-6} \mathrm{~mol} / \mathrm{l} ; \mathrm{H}+\mathrm{F} 7, \mathrm{HGPDS}+\mathrm{Flu} 10^{-7} \mathrm{~mol} / \mathrm{l} ; \mathrm{H}+\mathrm{F} 8$, HGPDS + Flu $10^{-8} \mathrm{~mol} / \mathrm{l}$ $\mathrm{H}+\mathrm{G}, \mathrm{HGPDS}+\mathrm{GSK} 65039410^{-5} \mathrm{~mol} / \mathrm{l} ; \mathrm{H}+\mathrm{P}, \mathrm{HGPDS}+\mathrm{PD} 98059$ $10^{-5} \mathrm{~mol} / \mathrm{l}$. (A) Analysis of PTN and VEGF mRNA expression by RT-PCR. (B) Densitometry analysis of PTN and VEGF mRNA. GAPDH was used as the housekeeping gene to normalize target gene expression. Flu inhibited the elevated PTN and VEGF mRNA expression induced by HGPDS in a dosedependent manner. ${ }^{*} \mathrm{P}<0.01$ vs. control, ${ }^{\#} \mathrm{P}<0.01,{ }^{+} \mathrm{P}<0.05$ vs. HGPDS.

Effect of HGPDS and Flu on the mRNA expression of PTN and $V E G F$. The mRNA expression of PTN measured by RT-PCR

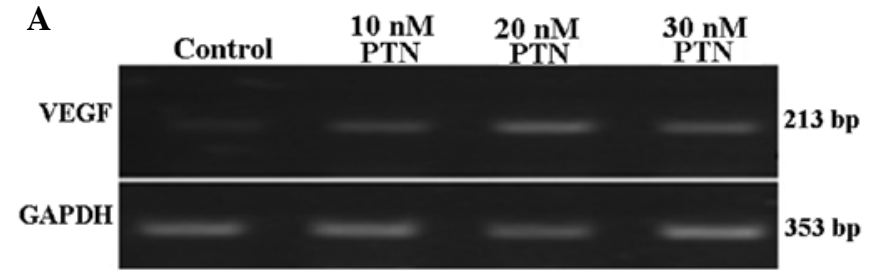

B

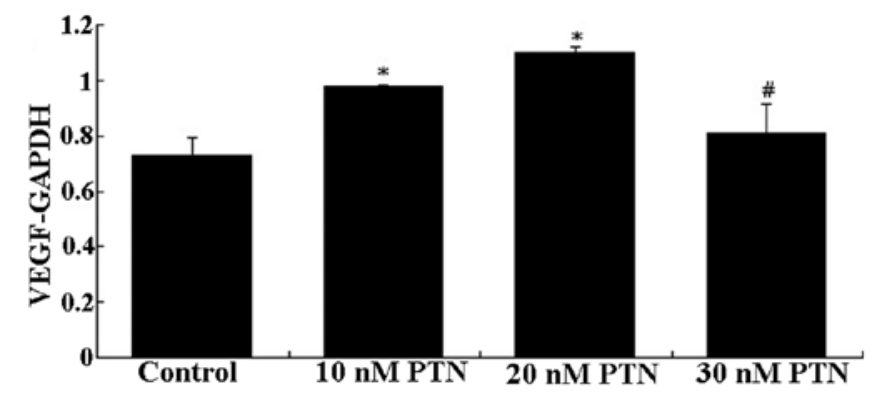

Figure 5. Effect of 10, 20 and $30 \mathrm{nmol} / \mathrm{l}$ pleiotrophin (PTN) on the expression of vascular endothelial growth factor (VEGF). (A) Analysis of VEGF mRNA expression by RT-PCR. (B) Densitometry analysis of VEGF mRNA. GAPDH was used as the housekeeping gene to normalize target gene expression. Different concentrations of PTN increased VEGF mRNA expression compared with the xcontrol group, $(\mathrm{P}<0.05)$ peaking at $20 \mathrm{nmol} / 1 \mathrm{PTN}$. ${ }^{*} \mathrm{P}<0.05$ vs. control group, ${ }^{\#} \mathrm{P}<0.05$ vs. $20 \mathrm{nmol} / 1 \mathrm{PTN}$.

in the HPMCs increased significantly following exposure to HGPDS, peaking at $6 \mathrm{~h}$. The VEGF mRNA levels were significantly elevated and peaked at $12 \mathrm{~h}$ following exposure to HGPDS $(\mathrm{P}<0.05)$ (Fig. 3). The effects of HGPDS in conjuction with 3 different concentrations of Flu, GSK650394 and PD98059 on PTN mRNA expression were examined in the HPMCs. GSK650394 (10 $\left.0^{-5} \mathrm{~mol} / \mathrm{l}\right)$, PD98059 $\left(10^{-5} \mathrm{~mol} / \mathrm{l}\right)$ and Flu $\left(10^{-6} \mathrm{~mol} / \mathrm{l}\right)$ significantly suppressed the upregulation in the expression of PTN and VEGF induced by HGPDS $(\mathrm{P}<0.05)$. However, Flu at the concentration of $10^{-7} \mathrm{~mol} / \mathrm{l}$ and $10^{-8} \mathrm{~mol} / 1$ had no significant effects on the elevated PTN and VEGF mRNA expression $(\mathrm{P}>0.05)$. Compared with the control group, Flu $\left(10^{-6} \mathrm{~mol} / \mathrm{l}\right)$, GSK650394 $\left(10^{-5} \mathrm{~mol} / \mathrm{l}\right)$ or PD98059 $\left(10^{-5} \mathrm{~mol} / \mathrm{l}\right)$ alone had no significant effects on PTN, VEGF and FN mRNA expression in the HPMCs ( $\mathrm{P}>0.05)$ (Fig. 4). Compared with the control group, the concentration of PTN (10-30 nmol/1) which had the most significant effect on the mRNA expression of VEGF was $20 \mathrm{nmol} / \mathrm{l}(\mathrm{P}<0.05)$ (Fig. 5). The blocking peptide of PTN decreased the mRNA expression of VEGF which had been increased by PTN (20 nmol/l) $(\mathrm{P}<0.05)$ (Fig. 6). However, it had no effect on the mRNA expression of FN which had been increased by PTN (Fig. 7).

Effect of HGPDS and Flu on the protein expression of PTN and $V E G F$. The protein expression of PTN measured by western blot analysis in the HPMCs increased significantly and peaked at $36 \mathrm{~h}$ following exposure to HGPDS. The VEGF protein levels were significantly elevated and peaked at $48 \mathrm{~h}$ following exposure to HGPDS $(\mathrm{P}<0.05)$ (Figs. 8 and 9). Based on the results (Figs. 8 and 9), we measured PTN and VEGF protein expression following exposure to HGPDS in conjunction with 3 different concentrations of Flu, GSK650394 and PD98059 in the HPMCs for $36 \mathrm{~h}$ and $48 \mathrm{~h}$. GSK650394 $\left(10^{-5} \mathrm{~mol} / \mathrm{l}\right)$, PD98059 (10 $\left.{ }^{-5} \mathrm{~mol} / \mathrm{l}\right)$ and Flu $\left(10^{-6} \mathrm{~mol} / \mathrm{l}\right)$ significantly inhib- 


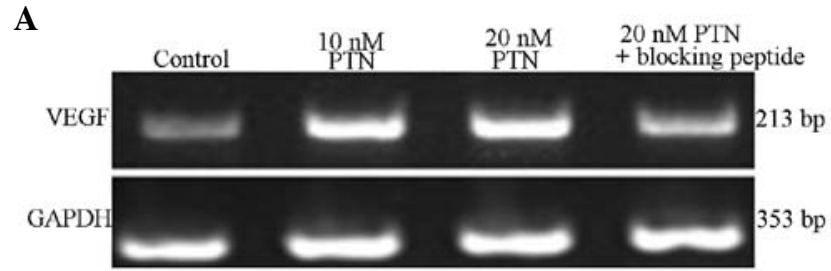

B

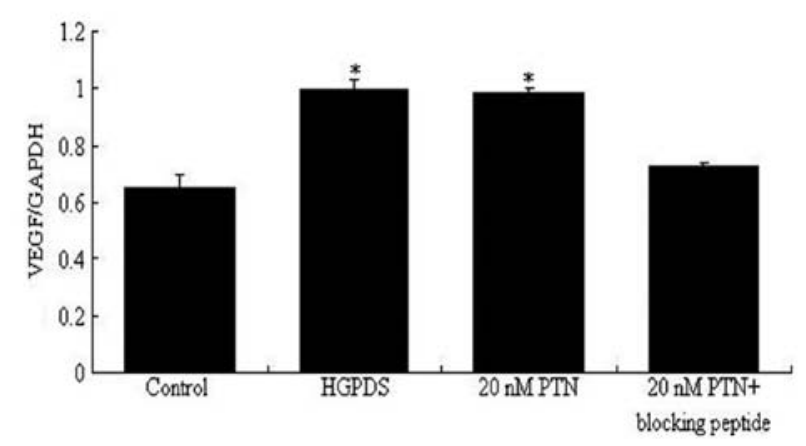

Figure 6. Effect of $20 \mathrm{nmol} / \mathrm{l}$ pleiotrophin (PTN) and blocking peptide of PTN on the expression of vascular endothelial growth factor (VEGF). (A) Analysis of VEGF mRNA expression by RT-PCR. (B) Densitometry analysis of VEGF mRNA. GAPDH was used as the housekeeping gene to normalize target gene expression. High-glucose-based peritoneal dialysis solution (HGPDS) and $20 \mathrm{nmol} / 1 \mathrm{PTN}$ increased VEGF expression compared with the control (" $\mathrm{P}<0.05) ; 20 \mathrm{nmol} / 1 \mathrm{PTN}+$ blocking peptide had no significant difference compared with control ( $\mathrm{P}>0.05)$.
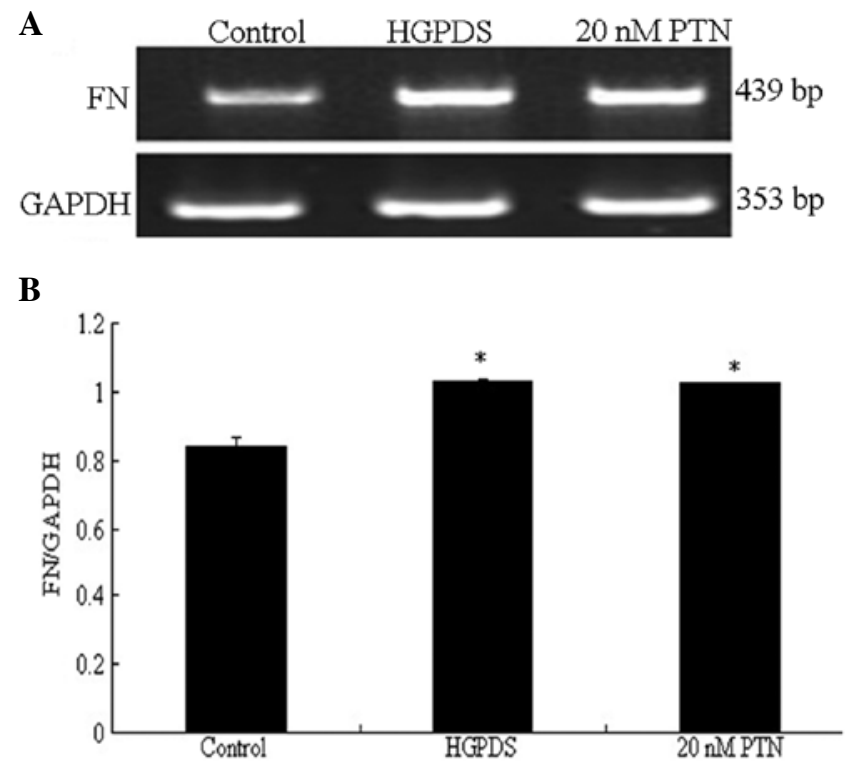

Figure 7. Effect of $20 \mathrm{nmol} / 1$ pleiotrophin (PTN) on the expression of fibronectin (FN). (A) Analysis of FN mRNA expression by RT-PCR. (B) Densitometry analysis of FN mRNA. GAPDH was used as the housekeeping gene to normalize target gene expression. High-glucose-based peritoneal dialysis solution (HGPDS) and $20 \mathrm{nmol} / \mathrm{l} \mathrm{PTN}$ increased FN expression compared with the control group $\left({ }^{*} \mathrm{P}<0.05\right)$.

ited the upregulation in PTN and VEGF expression induced by HGPDS $(\mathrm{P}<0.05)$. However, Flu at the concentration of $10^{-7}$ and $10^{-8} \mathrm{~mol} / \mathrm{l}$ had no significant effects on the elevated $\mathrm{PTN}$ and VEGF protein expression levels $(\mathrm{P}>0.05)$. Compared with the control group, Flu $\left(10^{-6} \mathrm{~mol} / \mathrm{l}\right)$, PD98059 $\left(10^{-5} \mathrm{~mol} / \mathrm{l}\right)$
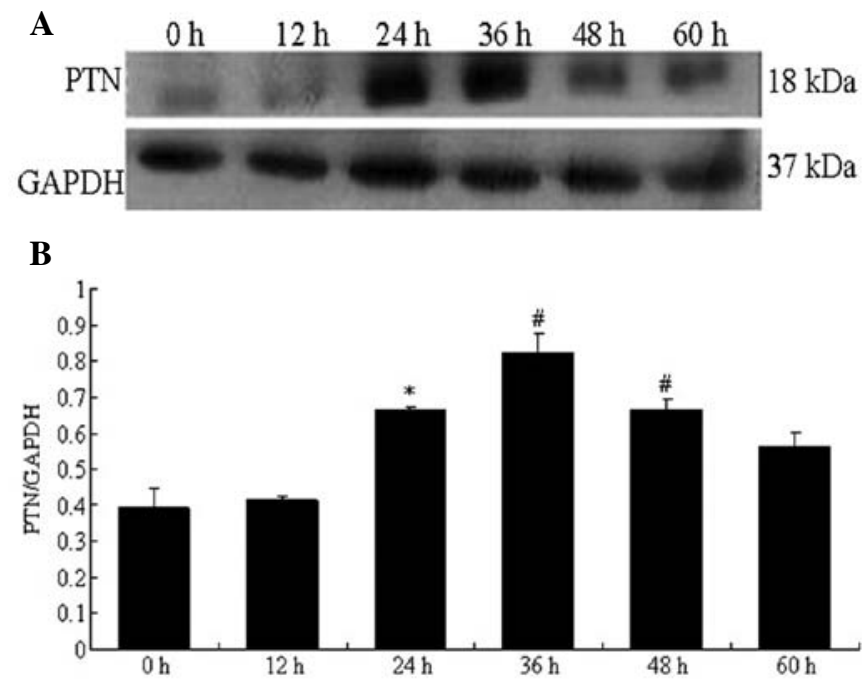

Figure 8. Effect of high-glucose-based peritoneal dialysis solution (HGPDS) on pleiotrophin (PTN) protein expression. (A) Analysis of PTN protein expression by western blot analysis. (B) Densitometry analysis of PTN protein. GAPDH was used as the housekeeping gene to normalize target gene expression. After incubation for the indicated periods of time, the protein expression of PTN increased significantly, peaking at $36 \mathrm{~h}$. ${ }^{*} \mathrm{P}<0.05$ vs. $0 \mathrm{~h}$, ${ }^{\#} \mathrm{P}<0.01$ vs. 0 h.
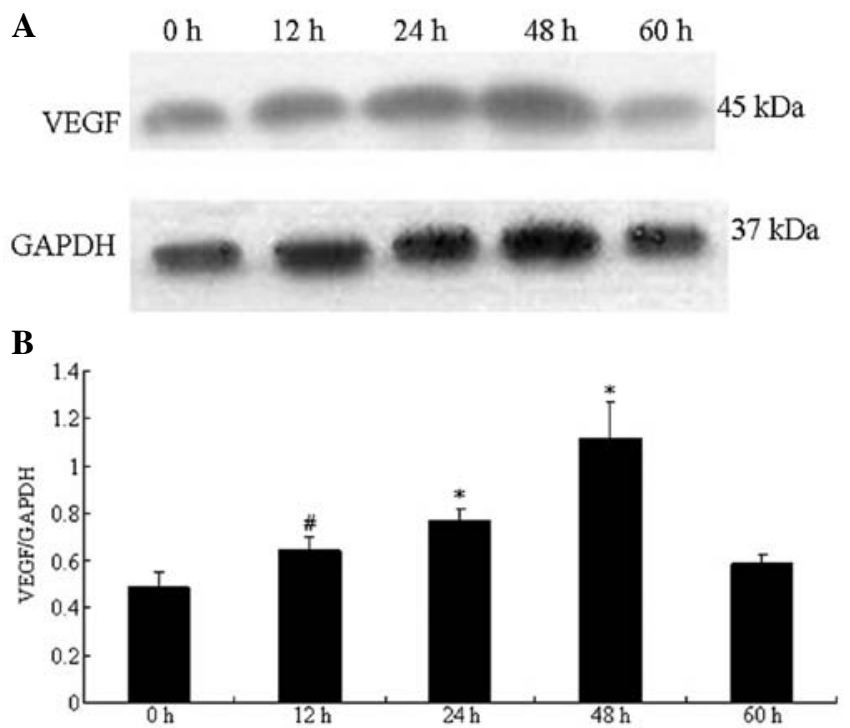

Figure 9. Effect of high-glucose-based peritoneal dialysis solution (HGPDS) on vascular endothelial growth factor (VEGF) protein expression. (A) Analysis of VEGF protein expression by western blot analysis. (B) Densitometry analysis of VEGF protein. GAPDH was used as the housekeeping gene to normalize target gene expression. After incubation for the indicated periods of time, the protein expression of VEGF increased significantly, peaking at $48 \mathrm{~h} .{ }^{~} \mathrm{P}<0.05$ vs. $0 \mathrm{~h},{ }^{,} \mathrm{P}<0.01$ vs. $0 \mathrm{~h}$.

or GSK650394 $\left(10^{-5} \mathrm{~mol} / \mathrm{l}\right)$ alone had no significant effects on PTN and VEGF protein expression in HPMCs $(\mathrm{P}>0.05)$ (Fig. 10). The effect of PTN on the expression of VEGF and FN was also examined. PTN (10-30 nmol/l) increased the expression of VEGF in the HPMCs; the concentration of $20 \mathrm{nmol} / 1 \mathrm{PTN}$ induced the most significant increase $(\mathrm{P}<0.05)$ (Fig. 11). The blocking peptide of PTN decreased the expression of VEGF which had been increased by PTN (Fig. 12). Compared with the control, $20 \mathrm{nmol} / \mathrm{l}$ of PTN increased the 
A

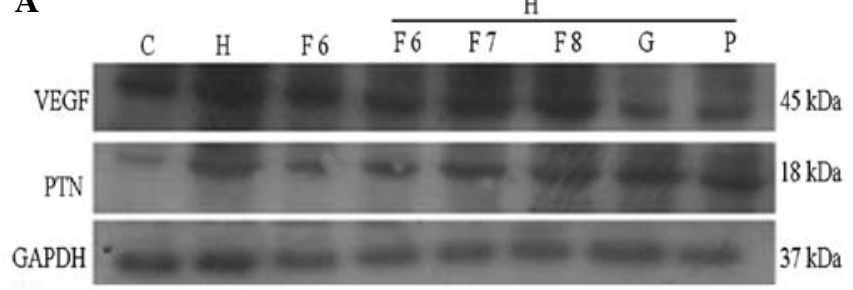

B

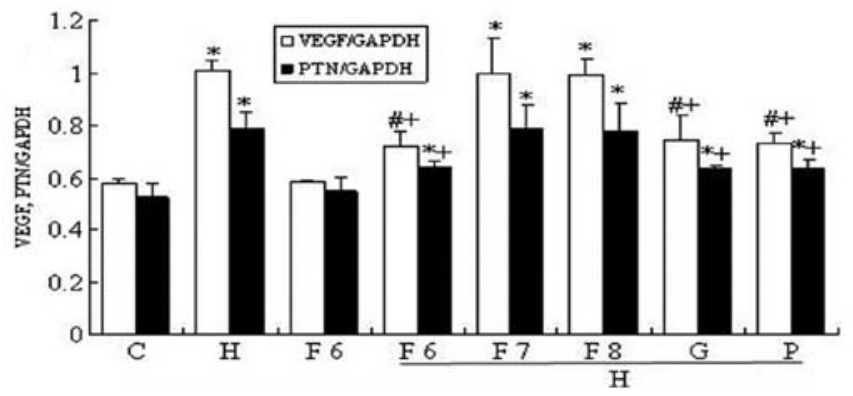

Figure 10. Effect of fluvastatin (Flu), GSK650394 (a competitive inhibitor of SGK1) and PD98059 (a competitive inhibitor of ERK1/2) on the high-glucosebased peritoneal dialysis solution (HGPDS)-stimulated protein expression of pleiotrophin (PTN) and vascular endothelial growth factor (VEGF). C, control; H, HGPDS; F6, Flu $10^{-6} \mathrm{~mol} / \mathrm{l} ; \mathrm{H}+\mathrm{F} 6$, HGPDS + Flu $10^{-6} \mathrm{~mol} / \mathrm{l}$; $\mathrm{H}+\mathrm{F} 7$, HGPDS + Flu $10^{-7} \mathrm{~mol} / \mathrm{l} ; \mathrm{H}+\mathrm{F} 8$, HGPDS + Flu $10^{-8} \mathrm{~mol} / \mathrm{l} ; \mathrm{H}+\mathrm{G}$, HGPDS + GSK650394 10-5 mol/l; H + P, HGPDS + PD98059 $10^{-5} \mathrm{~mol} / \mathrm{l}$ (A) Analysis of PTN and VEGF protein expression by western blot analysis. (B) Densitometry analysis of VEGF and PTN protein. GAPDH was used as the housekeeping gene to normalize target gene expression. After incubation for $36 \mathrm{~h}$ or $48 \mathrm{~h}$, Flu, GSK650394 and PD98059 inhibited the elevated PTN and VEGF protein expression induced by HGPDS in a dose-dependent manner. ${ }^{*} \mathrm{P}<0.05$ vs. control, ${ }^{,} \mathrm{P}<0.05$ vs. HGPDS, ${ }^{+} \mathrm{P}<0.05$ vs. HGPDS.
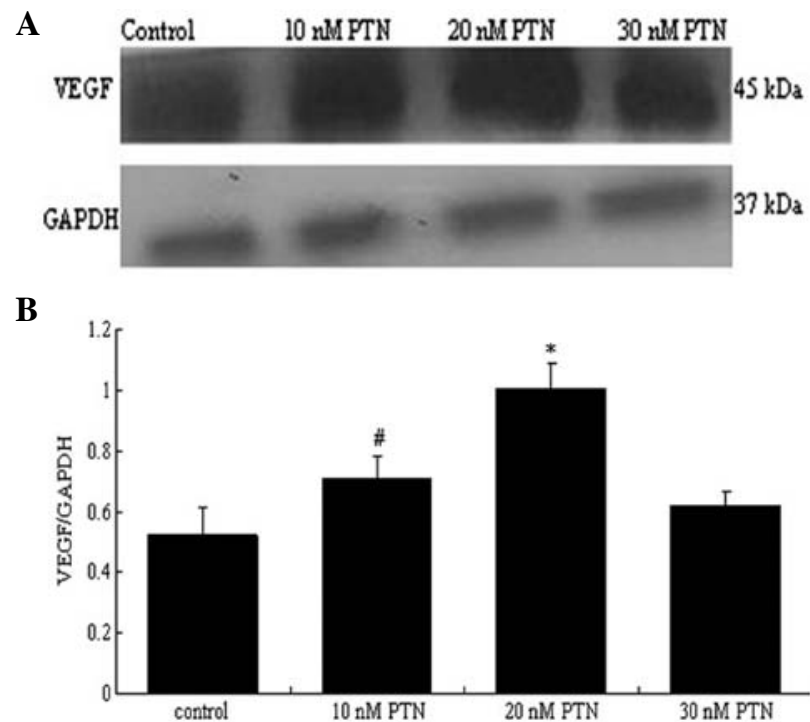

Figure 11. Effect of pleiotrophin (PTN) on the protein expression of vascular endothelial growth factor (VEGF). (A) Analysis of VEGF protein expression by western blot analysis. (B) Densitometry analysis of VEGF protein. GAPDH was used as the housekeeping gene to normalize target gene expression; $20 \mathrm{nmol} / 1 \mathrm{PTN}$ significantly increased VEGF expression. ${ }^{*} \mathrm{P}<0.01$ vs. control, ${ }^{\sharp} \mathrm{P}<0.05$ vs. control.

expression of FN $(\mathrm{P}<0.05)$. Our results indicated that PTN and HGPDS had the same effect on the expression of FN (Fig. 13). Flu $\left(10^{-6} \mathrm{~mol} / \mathrm{l}\right)$, PD98059 and GSK650394 decreased the
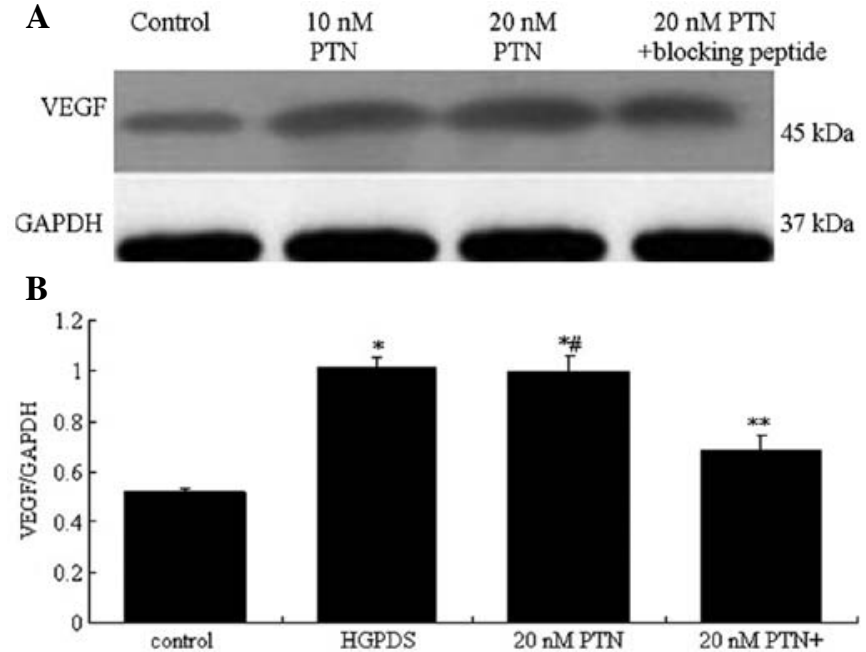

Figure 12. Effect of $20 \mathrm{nmol} / 1$ pleiotrophin (PTN) and blocking peptide of PTN on the expression of vascular endothelial growth factor (VEGF). (A) Analysis of VEGF protein by western blot analysis. (B) Densitometry analysis of VEGF protein. GAPDH was used as the housekeeping gene to normalize target gene expression. High-glucose-based peritoneal dialysis solution (HGPDS) and $20 \mathrm{nmol} / 1$ PTN increased VEGF expression compared with the control group; $\left({ }^{*} \mathrm{P}<0.01\right) 20 \mathrm{nmol} / 1 \mathrm{PTN}+$ blocking peptide reduced the expression of VEGF compared with $20 \mathrm{nmol} / \mathrm{l} \mathrm{PTN}$ alone. $\left({ }^{* *} \mathrm{P}<0.05\right)$, ${ }^{\text {\#}} \mathrm{P}<0.05$ vs. HGPDS.

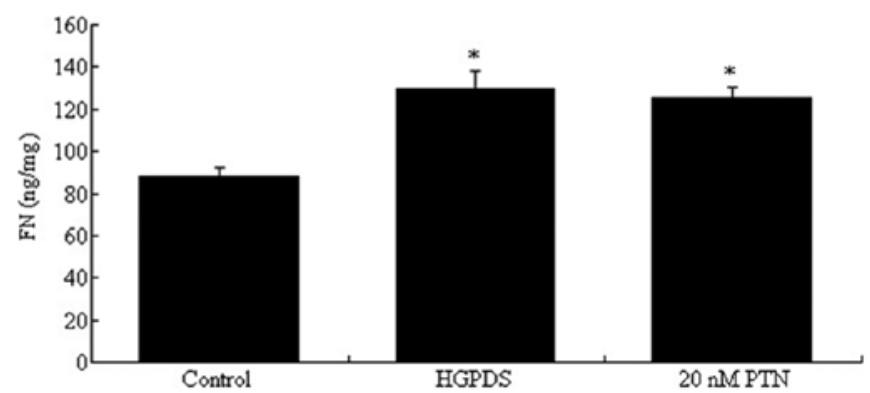

Figure 13. Effect of pleiotrophin (PTN) on fibronectin $(\mathrm{FN})$ protein expression by ELISA. PTN $(20 \mathrm{nmol} / \mathrm{l})$ increased the expression of FN, which had the same effect as high-glucose-based peritoneal dialysis solution (HGPDS). $\left({ }^{*} \mathrm{P}<0.05\right.$ vs. control.)

expression of p-ERK1/2 which had been increased by HGPDS $(\mathrm{P}<0.05)$ (Fig. 14). Flu, PD98059 and GSK650394 alone had no significant effect on the expression of $\mathrm{p}-\mathrm{ERK} 1 / 2$ compared with the control group ( $\mathrm{P}>0.05)$ (Fig. 15). The expression of p-ERK1/2 which had been increased by HGPDS peaked at $8 \mathrm{~h}$ $(\mathrm{P}<0.01$ or $\mathrm{P}<0.05)$ (Fig. 16)

\section{Discussion}

If the peritoneum is exposed to HGPDS continuously, HGPDS will lead to the alteration of the structure and function of the membrane. HGPDS may have the potential to increase peritoneal permeability, resulting in the rapid dissipation of the osmotic gradient and, eventually, causing ultrafiltration failure and inadequate dialysis (16). Decreased ultrafiltration has is regarded as evidence of the augmentation of the peritoneal surface area available for the diffusion exchange (17). An increased vascular surface area within the peritoneal membrane may thus account 

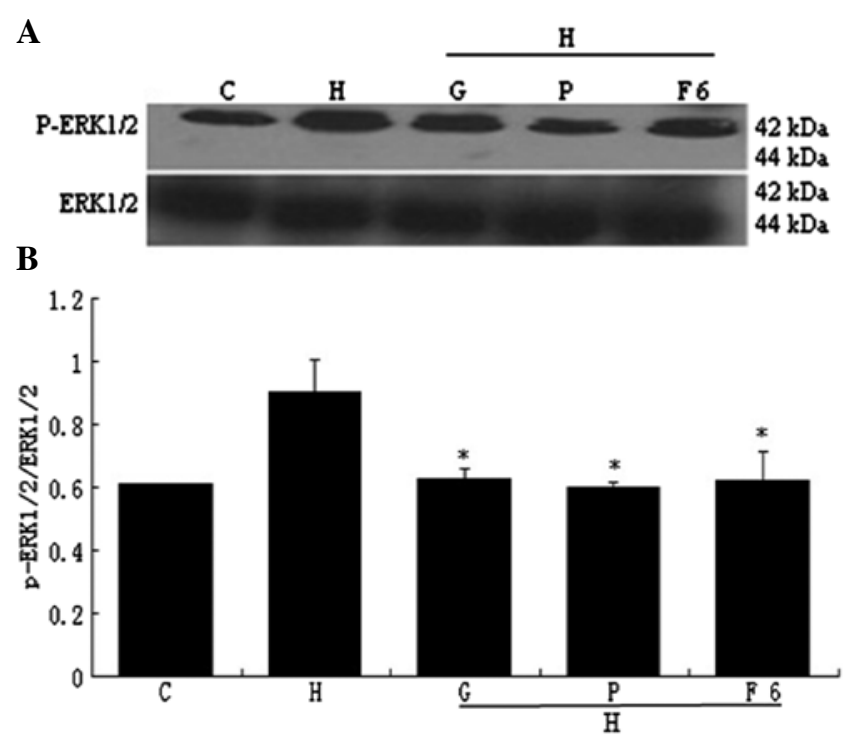

Figure 14. Effect of different factors on the protein expression of p-ERK1/2. $\mathrm{C}$, control; H, high-glucose-based peritoneal dialysis solution (HGPDS); F6, Flu $10^{-6} \mathrm{~mol} / \mathrm{l}$; G, GSK650394 (a competitive inhibitor of SGK1) $10^{-5} \mathrm{~mol} / \mathrm{l}$; P, PD98059 (a competitive inhibitor of ERK1/2) 10-5 mol/l. (A) Analysis of p-ERK $1 / 2$ protein expression by western blot analysis. (B) Densitometry analysis of p-ERK1/2 protein expression normalized based on ERK1/2. $($ ( $\mathrm{P}<0.05$ vs. HGPDS.)
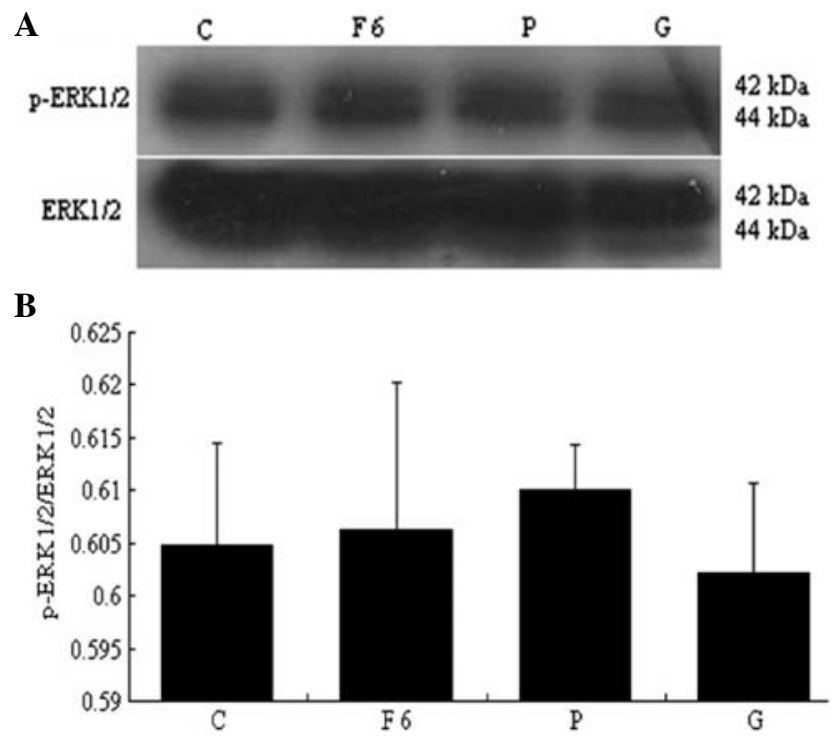

Figure 15. Effect of fluvastatin (Flu) or PD98059 (a competitive inhibitor of ERK1/2) or GSK650394 (a competitive inhibitor of SGK1) alone on the protein expression of p-ERK1/2. C, control; $\mathrm{H}$, high-glucose-based peritoneal dialysis solution (HGPDS); F6, Flu $10^{-6} \mathrm{~mol} / \mathrm{l}$; G, GSK650394 $10^{-5} \mathrm{~mol} / \mathrm{l} ; \mathrm{P}$, PD98059 $10^{-5} \mathrm{~mol} / \mathrm{l}$. (A) Analysis of $\mathrm{p}$-ERK1/2 protein expression by western blot analysis. (B) Densitometry analysis of p-ERK1/2 protein normalized based on ERK1/2 (there was no significant difference between the groups).

for the loss of ultrafiltration. Within this framework, VEGF may play a critical role in ultrafiltration failure, mainly as VEGF increases vascular permeability $(18,19)$. In the present study, we focused on the direct short-term effects of HGPDS on the expression of VEGF. Modulation of the expression and organization of VEGF by PTN in colorectal cancer has been reported (20). It has been reported that HPMCs secrete PTN,
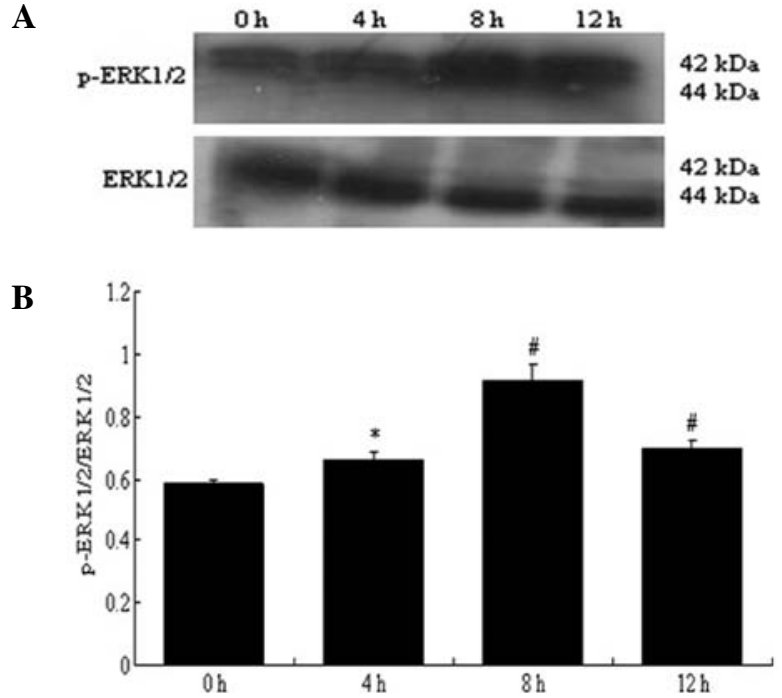

Figure 16. Effect of high-glucose-based peritoneal dialysis solution (HGPDS) on the protein expression of p-ERK1/2. (A) Analysis of $p$-ERK1/2 protein expression by western blot analysis. (B) Densitometry analysis of p-ERK1/2 protein normalized based on ERK1/2. After incubation for the indicated periods of time, the protein expression of p-ERK1/2 increased significantly, peaking at $8 \mathrm{~h}\left({ }^{*} \mathrm{P}<0.05\right.$ vs. $0 \mathrm{~h},{ }^{\#} \mathrm{P}<0.01$ vs. $\left.0 \mathrm{~h}\right)$.

then PTN increases peritoneal permeability which leads to peritoneal fibrosis in mice (15). Pleiotrophin (PTN the protein, ptn the gene), a 136 amino acid, secreted heparin-binding cytokine, can signal diverse functions, such as neurite outgrowth and angiogenesis. PTN may be a candidate 'tumor promoter' and may initiate an 'angiogenic switch' through its C-terminal angiogenesis domain (12).

In this study, we demonstrate that HGPDS upregulates VEGF expression in HPMCs in a time-dependent manner. Our in vitro data further confirm that HGPDS upregulates PTN expression in HPMCs. HGPDS significantly inhibited the viability of the HPMCs. In addition, the morphology of the HPMCs was altered from a typical cobblestone-like appearance to a fibroblast-like appearance following incubation with HGPDS for $48 \mathrm{~h}$. The same morphological changes were observed in the cells incubated in DMEM supplemented with 20-30 nmol/l PTN. Coinciding with the morphological changes, the mRNA and protein expression of PTN and VEGF increased significantly in the HPMCs in response to HGPDS. The increase in PTN expression occurred in a time-dependent manner and peaked prior to VEGF, which indicated that VEGF expression may be partially dependent on the secretion of PTN by HPMCs. When the HPMCs were incubated with PTN, the expression of VEGF significantly increased, particularly with the concentration of $20 \mathrm{nmol} / \mathrm{l} \mathrm{PTN}$. The blocking peptide of PTN blocked the effects of the C-terminal of PTN, which partially restored the morphological changes and suppressed the expression of VEGF in the HPMCs incubated with PTN. Our results also indicated that PTN significantly increased the expression of FN in the HPMCs; however, this increase was not reversed by the blocking peptide of PTN. Further investigation is required to determine whether any other blocking peptide can inhibit the expression of FN induced by PTN. Our results demonstrate that PTN may mediate the process of peritoneal membrane injury induced by HGPDS. However, the 
mechanisms behind the increase in PTN expression induced by HGPDS in HPMCs remain unclear.

SGK is a new member of the serine/threonine kinase gene family and was originally identified as an immediate early gene under acute transcriptional control by serum and glucocorticoids (21). Human $S g k-1$ was cloned as a cell volume-sensitive gene which is upregulated by hypertonic cell shrinkage (22). Evidence suggests that the expression, enzymatic activity and cellular localization of SGK1 are regulated in response to various stimuli. These stimuli include cell volume, epithelial transport, cardiac action potential and cell proliferation, survival and apoptosis $(23,24)$. SGK1 is expressed in a variety of fibrosing tissues, such as tissues in Crohn's disease, lung fibrosis, liver cirrhosis and glomerulonephritis $(25,26)$. ERK1 and ERK2 belong to the protein-serine/threonine kinase family which participates in the Ras-Raf-MEK-ERK signal transduction cascade. This cascade is involved in the regulation of a large variety of processes, such as cell cycle progression, cell migration, cell survival, differentiation, proliferation and transcription (27). Advanced glycation end products (AGEs) can induce ERK1/2 phosphorylation in skin cells (28). In the present study, GSK650394 or PD98059 decreased the mRNA and protein expression of PTN in the HPMCs which had been increased by HGPDS. The correlation between SGK1 and ERK1/2 is poorly understood. Therefore, the correlation between SGK1 and ERK1/2 was investigated further in this study. We found that $\mathrm{p}$-ERK1/2 expression was reduced by the addition of GSK650394, an inhibitor of SGK1, suggesting that SGK1 may regulate the phosphorylation of ERK1/2 and that the SGK1-ERK1/2 pathway may play a role in the increased expression of PTN in HPMCs induced by HGPDS. GSK650394 or PD98059 only partially inhibited the expression of PTN and VEGF in the HPMCs which had been increased by HGPDS. Therefore, there are many other signaling pathways that participate in this injury process. Further studies are required to elucidate this issue.

Statins inhibit the enzyme, 3-hydroxy-3-methylglutarylcoenzyme A (HMG-CoA) reductase, which is required for cholesterol biosynthesis. However, there is increasing evidence of the beneficial effects of statins, unrelated to their lipid-lowering capacity, such as anti-fibrinolytic, anti-proliferative and ant-inflammatory effects (29). By inhibiting HMG-CoA reductase, statins can also inhibit the synthesis of isoprenoids, which are important for intracellular signaling molecules, such as ERK, Rho, Ras and Rac. Therefore, statins have various cholesterol-independent effects, such as the reduction of extracellular matrix synthesis, the regulation of cytokines and inflammatory factors through the direct inhibition of these small GTP-binding proteins (30). Previous studies have demonstrated that SGK1 was the functional cross of multiple signaling pathways $(31,32)$. It can be activated by bone marrow kinase/extracellular signal-regulated kinase 5 (BK/ ERK5) or p38 MAPK. In addition, the small G protein Rac1 activates SGK1 through a PI3-kinase-independent pathway $(33,34)$. Additional activators of SGK1 include neuronal depolarization, cAMP, lithium and oxidation (35). The present study did not explore the underlying mechanisms of PTN regulation in response to Flu. Further studies on statins are required to investigate the mechanisms by which statins mediate PTN expression. Our study confirms that statins reduce PTN expression in HPMCs induced by HGPDS.
In conclusion, the present study demonstrates that PTN expression induced by HGPDS consequently alters the expression of VEGF in HPMCs. This upregulation in PTN expression induced by HGPDS provides further support for the role of PTN in peritoneal permeability and fibrosis in continuous ambulatory peritoneal dialysis (CAPD). Our findings provide additional insight into the mechanisms involved in the induction of the expression of PTN and VEGF in HPMCs by HGPDS and the prevention of ultrafiltration failure in CAPD, although the exact pathophysiological effects of the long-term exposure of HPMCs to glucose degradation products remain to be elucidated.

\section{Acknowledgements}

The present study was funded by the Priority Academic Program Development (PAPD) of Jiangsu Higher Education Institutions.

\section{References}

1. He Z, Potter R, Li X and Flessner M: Stretch of human mesothelial cells increases cytokine expression. Adv Perit Dial 28: 2-9, 2012.

2. Loureiro J, Aguilera A, Selgas R, et al: Blocking TGF- $\beta 1$ protects the peritoneal membrane from dialysate-induced damage: J Am Soc Nephrol 22: 1682-1695, 2011.

3. Mizutani M, Ito Y, Mizuno M, et al: Connective tissue growth factor $(\mathrm{CTGF} / \mathrm{CCN} 2)$ is increased in peritoneal dialysis patients with high peritoneal solute transport rate. Am J Physiol Renal Physiol 298: F721-F733, 2010.

4. Yokoi H, Kasahara M, Mori K, et al: Peritoneal fibrosis and high transport are induced in mildly pre-injured peritoneum by 3,4-didexoxyglucosone-3-ene in mice. Perit Dial Int 33: 143-154, 2013.

5. Heimbürger O, Waniewski J, Werynski A, et al: Peritoneal transport in CAPD patients with permanent loss of ultrafiltration capacity. Kidney Int 38: 495-506, 1990.

6. Davies SJ, Phillips L, Naish PF and Russell GI: Peritoneal glucose exposure and changes in membrane solute transport with time on peritoneal dialysis. J Am Soc Nephrol 12: 1046-1051, 2001.

7. Plum J, Hermann S, Fussholler A, et al: Peritoneal sclerosis in peritoneal dialysis patients related to dialysis settings and peritoneal transport properties. Kidney Int Suppl 78: S42-S47, 2001.

8. Zweers MM, de Waart DR, Smit W, et al: Growth factors VEGF and TGF-beta1 in peritoneal dialysis. J Lab Clin Med 134: 124-132, 1999.

9. Zweers MM, Struijk DG, Smit W and Krediet RT: Vascular endothelial growth factor in peritoneal dialysis: a longitudinal follow-up. J Lab Clin Med 137: 125-132, 2001.

10. Milner PG, Li YS, Hoffman RM, et al: A novel 17 kD heparinbinding growth factor (HBGF-8) in bovine uterus: purification and N-terminal amino acid sequence. Biochem Biophys Res Commun 165: 1096-1103, 1989.

11. Rauvala H: An 18-kd heparin-binding protein of developing brain that is distinct from fibroblast growth factors. EMBO J 8: 2933-2941, 1989.

12. Deuel TF, Zhang N, Yeh HJ, et al: Pleiotrophin: a cytokine with diverse functions and a novel signaling pathway. Arch Biochem Biophys 397: 162-171, 2002.

13. Kohashi T, Tateaki Y, Tateno C, et al: Expression of pleiotrophin in hepatic nonparenchymal cells and preneoplastic nodules in carbon tetrachloride-induced fibrotic rat liver. Growth Factors 20: 53-60, 2002.

14. Henger A, Kretzler M, Doran P, et al: Gene expression fingerprints in human tubulointerstitial inflammation and fibrosis as prognostic markers of disease progression. Kidney Int 65: 904-917, 2004.

15. Yokoi H, Kasahara M, Mori K, et al: Pleiotrophin triggers inflammation and increased peritoneal permeability leading to peritoneal fibrosis. Kidney Int 81: 160-169, 2012.

16. Jorres A and Witowski J: PD membrane: biological responses to different PD fluids. Contrib Nephrol 150: 48-53, 2006. 
17. Vrtovsnik F, Coester AM, Lopes-Barreto D, et al: Induction of chronic kidney failure in a long-term peritoneal exposure model in the rat: effects on functional and structural peritoneal alterations. Perit Dial Int 30: 558-569, 2010

18. De Vriese AS, Mortier S and Lameire NH: Glucotoxicity of the peritoneal membrane: the case for VEGF. Nephrol Dial Transplant 16: 2299-2302, 2001.

19. Szeto CC, Wong TY, Lai KB, et al: The role of vascular endothelial growth factor in peritoneal hyperpermeability during CAPD-related peritonitis. Perit Dial Int 22: 265-267, 2002.

20. Kong Y, Bai PS, Nan KJ, et al: Pleiotrophin is a potential colorectal cancer prognostic factor that promotes VEGF expression and induces angiogenesis in colorectal cancer. Int J Colorectal Dis 27: 287-298, 2012.

21. Saad S, Stevens VA, Wassef L, et al: High glucose transactivates the EGF receptor and up-regulates serum glucocorticoid kinase in the proximal tubule. Kidney Int 68: 985-997, 2005.

22. Waldegger S, Barth P, Raber G and Lang F: Cloning and characterization of a putative human serine/threonine protein kinase transcriptionally modified during anisotonic and isotonic alterations of cell volume. Proc Natl Acad Sci USA 94: 4440-4445, 1997.

23. Firestone GL, Giampaolo JR and O'Keeffe BA: Stimulusdependent regulation of serum and glucocorticoid inducible protein kinase (SGK) transcription, subcellular localization and enzymatic activity. Cell Physiol Biochem 13: 1-12, 2003.

24. Lang F and Cohen P: Regulation and physiological roles of serum- and glucocorticoid-induced protein kinase isoforms. Sci STKE 2001: re17, 2001

25. Waerntges S, Klingel K, Weigert $\mathrm{C}$, et al: Excessive transcription of the human serum- and glucocorticoid dependent kinase hSGK1 in lung fibrosis. Cell Physiol Biochem 12: 135-142, 2002.

26. Fillon S, Klingel K, Warntges S, et al: Expression of the serine/ threonine kinase hSGK1 in chronic viral hepatitis. Cell Physiol Biochem 12: 47-54, 2002.
27. Roskoski R Jr: ERK1/2 MAP kinases: structure, function, and regulation. Pharmacol Res 66: 105-143, 2012.

28. Zhu P, Ren M, Yang C, et al: Involvement of RAGE, MAPK and $\mathrm{NF}-\kappa \mathrm{B}$ pathways in AGEs-induced MMP-9 activation in HaCaT keratinocytes. Exp Dermatol 21: 123-129, 2012.

29. Vasan RS, Sullivan LM, Roubenoff R, et al: Inflammatory markers and the risk of heart failure in elderly subjects without prior myocardial infarction: the Framingham heart study. Circulation 107: 1486-1491, 2003.

30. Yokota T, Utsunomiya K, Murakawa Y, et al: Mechanism of preventive effect of HMG-CoA reductase inhibitor on diabetic nephropathy. Kidney Int Suppl 71: S178-S181, 1999.

31. Hayashi M, Tapping RI, Chao TH, et al: BMK1 mediates growth factor-induced cell proliferation through direct cellular activation of serum and glucocorticoid-inducible kinase. J Biol Chem 276: 8631-8634, 2001.

32. Mizuno $\mathrm{H}$ and Nishida E: The ERK MAP kinase pathway mediates induction of SGK (serum- and glucocorticoid-inducible kinase) by growth factors. Genes Cells 6: 261-268, 2001.

33. Meng F, Yamagiwa Y, Taffetani S, et al: IL-6 activates serum and glucocorticoid kinase via p38alpha mitogen-activated protein kinase pathway. Am J Physiol Cell Physiol 289: C971-C981, 2005.

34. Shelly $\mathrm{C}$ and Herrera R: Activation of SGK1 by HGF, Rac1 and integrin-mediated cell adhesion in MDCK cells: PI-3K-dependent and -independent pathways. J Cell Sci 115: 1985-1993, 2002.

35. Prasad N, Topping RS, Zhou D and Decker SJ: Oxidative stress and vanadate induce tyrosine phosphorylation of phosphoinositide-dependent kinase 1(PDK1). Biochemistry 39: 6929-6935, 2000. 